\title{
Moldovan - EU Economic Cooperation: The Role and Potential of Agricultural Sector
}

\author{
SECRIERU, Vladislav ${ }^{a}$; TERSKAYA, Galina A. ${ }^{b}$; SOLOVYKH, Nadezda N. ${ }^{c}$ \\ a. Department of World Economy and International Business, Financial University under the Government of the Russian Federation, Moscow, Russia. \\ b. Department of Economic Theory, Financial University under the Government of the Russian Federation, Moscow, Russia. \\ c. Department of Economic Theory, Financial University under the Government of the Russian Federation, Moscow, Russia.
}

PUBLISHED: 19/10/2021

Accepted: $18 / 10 / 2021$

Submitted: 09/10/2021

\section{COPYRIGHT NOTICE:}

\section{CITE THIS PAPER:}

Secrieru, Vladislav; Terskaya, Galina A.; Solovykh, Nadezda N. 2021. " Moldovan- EU Economic Cooperation: The Role and Potential of Agricultural Sector" Journal of World Economy: Transformations \& Transitions (JOWETT) 1(02):04. DOI: https://doi.org/10.52459/jowett1241021

\section{ABSTRACT}

Agriculture is one of the most important aspects of every country's economy. The Republic of Moldova enjoys a competitive advantage in agricultural output due to its excellent soil and temperate temperature. The Association Agreement between Moldova and the European Union (EU), which was signed in 2014, greatly increased Moldovan producers' access to EU markets. The EU is Moldova's most significant economic partner, accounting for over 70\% of the country's exports in 2019. In general, integrating Moldovan food producers into global value chains through supply chain connections with big retailers and exports helps them to scale up, improve productivity, and eventually contribute more to Moldova's economic growth. The developments in Moldova's agricultural and food trade following the establishment of the Deep and Comprehensive Free Trade Agreement (DCFTA) with the European Union are examined in this study. The study will look at Moldova's foreign trade activities from the standpoint of agriculture and food goods.

\section{KEYWORDS}

Moldova, EU, Agriculture, Economic Cooperation, DCFTA 


\section{INTRODUCTION}

Agriculture is one of the most important aspects of every country's economy. Agriculture in the majority of the world's countries has experienced a profound shift in recent decades as a result of increased innovation and the application of new technology. As a result, the agricultural industry as a whole has seen an improvement in production and effectiveness. Agriculture, independent of its technical development, has been shown to have a beneficial influence on economic growth since 1961 (Anderson et al., 2014).

The Republic of Moldova enjoys a competitive advantage in agricultural output due to its excellent soil and temperate temperature. In consequence, the availability of horticulture crops is a significant competitive advantage for food processing, which accounts for $37 \%$ of total industrial production and $26 \%$ of manufacturing jobs. Because of the prospects provided by advancements in food retail and foreign markets, this industry has a strong potential for continued expansion (Garmann, 2014).

Due to the expansion of multinational retail chains and major investments, Moldova's food-retail sector has developed significantly over the previous decade. At the same time, Moldova, and the European Union (EU) signed an Association Agreement in 2014, which considerably increased Moldovan producers' access to EU markets. The EU is Moldova's most significant economic partner, accounting for over $70 \%$ of the country's exports in 2019 (Kumar, 2015).

In general, integrating Moldovan food producers into global value chains through supply chain connections with big retailers and exports helps them to scale up, improve productivity, and eventually contribute more to Moldova's economic growth. Moldovan food manufacturers are eager to join global value chains, according to the he Organization for Economic Co-operation and Development (OECD) Enterprise Survey: 77 percent of the firms polled said they wanted to start or extend their collaboration with retail chains, and 85 percent said they wanted to start or increase their exports (Awokuse and Ruizhi, 2014).

Small producers, then again, as often as possible battle to incorporate into significant retailers' stock chains and develop into unfamiliar business sectors. As per the OECD Enterprise Survey, not exactly 50\% of little medium measured food processors straightforwardly supply general stores, and over $40 \%$ don't make any income from trades. The reasons for the present circumstance are various: little medium food processors' general helpless intensity, stresses over sanitation norms, inadequate administration abilities, and an absence of commodity and linkage help programs all frustrate their coordination into worldwide worth chains (Fathipour and Ghahremanlou, 2014).

\section{ECONOMIC AGREEMENTS}

European and the Moldovan Governments have been dealing with making conditions that would improve economic cooperation. For this reason, they have consented to a few agreements that emphatically 
affect the improvement of financial relations between these nations. Up until now, Republic of Moldova and Europe have consented to 25 Arrangements with economic character (Caliendo and Rossi, 2012).

Agreement between the European and the Government of the Republic of Moldova on the advancement and proportional assurance of ventures, endorsed in 1998 in Athens, Greece. This speculation arrangement between Europe, which is a created nation and Moldova, which is an agricultural nation, is a fundamental instrument of worldwide venture security. It builds up standards of treatment of unfamiliar financial backers on the region of the host state (Lileeva and Trefler, 2010).

Economic, scientific cooperation and technical agreement between the European Union and the Republic of Moldova's government. Moldova and Europe have consented to collaborate in the fields of common premium, such as communications and transportation, environment and the agriculture, tourism, consumer protection, innovation and science, architecture and construction, investments, and other forms of cooperation, according to this agreement. As a result, a Joint Committee was formed to oversee the agreement's implementation. Its inaugural meeting took place in Athens in 2007. Because Europe is an essential economic partner for Moldova, the Joint Committee works hard to foster economic relations by urging enterprises to engage actively (Smith et al., 2018).

Furthermore, the Committee's secretary indicated that Greece is very interested in expanding its collaboration with Moldova. As a result, the Committee is also responsible for promoting direct communication between economic agents from both nations. Other significant agreements were made to establish a firm legal foundation for the growth of business partnerships. Because Greece is a member of the European Union, the agreements between the EU and Moldova automatically have an influence on Moldovan-Greek ties (Cenusa et al., 2014).

In the framework of Moldovan-EU ties, it's worth noting that, in addition to collaboration, the EU promotes Moldova's political and economic integration. In this regard, Moldova and the EU concluded an Association Agreement in 2014, which included a Deep and Comprehensive Free Trade Area. As a consequence, Moldovans may now travel to the Schengen region without a visa, making it easier for them to visit as tourists. Furthermore, the EU helps Moldova with programs focusing on agriculture, police reform and rural development, among other things. In terms of commerce, Moldova has boosted its exports to the EU as a result of the Free Trade Area (Cimpoies, 2016).

\section{ECONOMIC RELATIONS BETWEEN EUROPE AND MOLDOVA}

As of 2015 according to the traded quantities, the major items Moldova shipped to Europe in 2014 were vegetable products, notably cereals, as well as nuts and edible fruit. It is clear that Moldova exports primarily raw resources and agricultural goods to Europe, which basically do not help much to the Moldovan economy due to their low added value (Cantir and Kennedy, 2015). 
Within six years up to 2018, the amount of commerce between Europe and Moldova has dropped substantially, from $\$ 111063$ thousands to $\$ 45123.4$ thousands. This is a 2.5 -fold decrease. However, following several years of negative commercial balances with Europe, Moldova had higher exports than imports from Greece in 2015, resulting in a $\$ 5702$ thousand positive commercial balance. Furthermore, in 2015, exports to Europe amounted for 1.29 percent of overall exports, while imports from Europe accounted for 0.49 percent of total imports, according to Moldova's total trade volume globally. In addition, the ratio of exports to Europe has quadrupled since 2012, indicating a considerable increase in Moldovan trade with the Europe (Ortikov and Vacek, 2018).

In terms of exports, Europe is now becoming a significant trading partner. It seems that Moldovan goods are growing more appealing to European customers, and that Moldovan manufacturers' exporting circumstances to Europe have increased. The proportion of European imports to total Moldovan imports has been continuously declining. If Europe was a key trading partner for Moldova in terms of imports in 2010, it has shrunk by nearly five times in 2015. It appears that the barriers to European export to Moldova have become more severe, and/or that the Moldovan marketplace is no longer appealing to European exporters, based on market size and consumer spending power (Kemoklidze and Wolff, 2019).

The researchers Nilsson and Silander (2016) suggest that Moldova should place a greater emphasis on industrial exports. In 2014, Moldova imported the following items from Europe: Vegetable products, notably nuts and edible fruit; melons and citrus fruit peels, fertilizers predominate and pharmaceuticals; mineral oils, Mineral fuels, and distillation products, mineral waxes and bituminous substances; Nuclear reactors, equipment, boilers, and mechanical appliances; Foodstuffs that have been prepared; spirits, drinks, and vinegar; tobacco and manufactured tobacco substitutes; plastics and products made of plastic; rubber and goods made of rubber. As a result, Moldova imports numerous items from Europe, such as citrus fruits, peaches, strawberries, and other fruits that can't or can only be grown to a limited degree in Moldova owing to colder climatic conditions than in Europe. It also imports industrial items, which have a higher economic worth.

Based on the data as of 2020, Moldova has the 38th place in both top destinations and top origins between EU agri-food trade partners. In the Table 1 the Moldova's most exported agricultural and food goods to the EU market have been provided based on the EU agri-food trade statistical factsheet (EU Factsheet, 2021) with the average values for 2016-2020. 
Table 1: Evolution of 20 top EU Agri-Food imports from Moldova, 2016 - 2020

\begin{tabular}{|c|c|c|c|c|c|c|c|c|}
\hline & & \multicolumn{7}{|c|}{ Imports } \\
\hline & & \multicolumn{5}{|c|}{$\begin{array}{l}\text { Value (million } \\
\text { EUR) }\end{array}$} & \multicolumn{2}{|c|}{$\%$} \\
\hline & & 2016 & 2017 & 2018 & 2019 & 2020 & $\begin{array}{c}\text { Share in all } \\
\text { Agri } 2020\end{array}$ & $\begin{array}{c}\text { Change } \\
2019-2020\end{array}$ \\
\hline 1 & Oilseeds, other than soyabeans & 95 & 147 & 124 & 142 & 111 & 21.3 & -21.8 \\
\hline 2 & Vegetable oils other than palm \& olive oils & 37 & 48 & 54 & 63 & 85 & 16.3 & 34.9 \\
\hline 3 & Wine, vermouth, cider, and vinegar & 32 & 37 & 44 & 43 & 50 & 9.6 & 16.3 \\
\hline 4 & Cereals, other than wheat and rice & 44 & 52 & 96 & 62 & 44 & 8.4 & -29.0 \\
\hline 5 & Fruit juices & 22 & 46 & 21 & 43 & 44 & 8.4 & 2.3 \\
\hline 6 & Tropical fruit, fresh or dried, nuts and spices & 58 & 64 & 64 & 51 & 43 & 8.2 & -15.7 \\
\hline 7 & Fruit, fresh or dried, excl. citrus \& tropical fruit & 16 & 30 & 23 & 26 & 30 & 5.7 & 15.4 \\
\hline 8 & Ethanol & 10 & 12 & 10 & 11 & 20 & 3.8 & 81.8 \\
\hline 9 & Preparations of vegetables, fruit, or nuts & 5 & 7 & 8 & 11 & 17 & 3.3 & 54.5 \\
\hline 10 & Wheat & 76 & 100 & 70 & 64 & 14 & 2.7 & -78.1 \\
\hline 11 & Pasta, pastry, biscuits, and bread & 11 & 10 & 11 & 11 & 12 & 2.3 & 9.1 \\
\hline 12 & Oilcakes & 7 & 4 & 2 & 5 & 8 & 1.5 & 60.0 \\
\hline 13 & Eggs and honey & 7 & 12 & 9 & 10 & 6 & 1.1 & -40.0 \\
\hline 14 & Spirits and liqueurs & 4 & 4 & 5 & 7 & 6 & 1.1 & -14.3 \\
\hline 15 & Chocolate, confectionery, and ice cream & 5 & 6 & 5 & 6 & 6 & 1.1 & 0.0 \\
\hline 16 & Other feed and feed ingredients & 3 & 5 & 4 & 5 & 4 & 0.8 & -20.0 \\
\hline 17 & Soyabeans & 5 & 5 & 4 & 5 & 4 & 0.8 & -20.0 \\
\hline 18 & Beet and cane sugar & 36 & 20 & 10 & 3 & 4 & 0.8 & 33.3 \\
\hline 19 & Essential oils & 3 & 3 & 4 & 4 & 3 & 0.6 & -25.0 \\
\hline \multirow[t]{2}{*}{20} & Vegetables, fresh, chilled, and dried & 2 & 3 & 4 & 6 & 2 & 0.4 & -66.7 \\
\hline & Remaining Agri-Food products & 13 & 10 & 10 & 11 & 10 & 1.9 & -9.1 \\
\hline
\end{tabular}

In the Table 2 the evolution of agricultural imports from Moldova by different countries has been provided based on the data collected from the National Bureau of Statistics of the Republic of Moldova (NBS, 2021).

Table 2. Agricultural imports from Moldova by countries

\begin{tabular}{|c|c|c|c|c|c|}
\hline & 2000 & 2005 & 2010 & 2015 & 2020 \\
\hline \multicolumn{6}{|c|}{ Trade Value (USD) } \\
\hline Ukraine & 17,86 & 42,77 & 34,80 & 64,15 & 122,90 \\
\hline Russia & 177,73 & 204,74 & 294,49 & 283,27 & 81,70 \\
\hline Belarus & 19,76 & 35,75 & 54,65 & 66,42 & 67,71 \\
\hline Romania & 21,93 & 30,66 & 28,87 & 15,12 & 56,73 \\
\hline Kazakhstan & 4,18 & 5,46 & 13,20 & 9,03 & 30,92 \\
\hline Austria & 3,31 & 6,42 & 6,43 & 13,38 & 25,11 \\
\hline Germany & 5,39 & 9,08 & 10,59 & 6,42 & 24,13 \\
\hline Switzerland & 0,95 & 1,67 & 0,07 & 13,77 & 21,37 \\
\hline France & 7,12 & 9,90 & 9,01 & 9,27 & 19,19 \\
\hline Poland & 0,63 & 1,27 & 3,28 & 171,93 & 14,07 \\
\hline EU-27 & 66,79 & 99,95 & 143,94 & 126,19 & 186,42 \\
\hline EU-25 & 42,04 & 66,67 & 112,15 & 95,12 & 124,17 \\
\hline EU-15 & 28,19 & 45,24 & 89,95 & 57,43 & 91,26 \\
\hline
\end{tabular}




\section{ROLE OF DCFTA IN TRADE BETWEEN EU AND MOLDOVA}

The Republic of Moldova and the European Union signed an Association Agreement (AA) on September 1, 2014, which included articles pertaining to the Deep and Comprehensive Free Trade Area (DCFTA). The DCFTA is a trade agreement between the EU and Moldova that intends to remove tariff and non-tariff obstacles to trade. The DCFTA comprises legally enforceable rules-based elements as well as a reform agenda based on cooperation to harmonize laws, norms, and product safety standards that continue to be trade obstacles. Five years after its origin, there is proof to help the view that the DCFTA hosts been gainful for the two gatherings and the European Union has turned into Moldova's principle exchanging accomplice (Gudim, 2014).

The EU accounted for around 70\% of Moldova's overall exports and 50\% of its total imports in 2018. Despite early reservations about the agri-food sector's lack of competitiveness, the DCFTA's prospects have exceeded expectations. Exports of agri-food items (both fresh and processed) benefited more than industrial products. Exports of agri-food goods have grown by USD 820 million (2015-2018) since the DCFTA's introduction, a 52 percent increase over 2011-2014.

This includes the export of items that are subject to yearly tariff quotas that are duty-free, and those that are subjected to the subversion mechanism (barley, corn, wheat, ethyl alcohol). Sunflower seeds (up 2.7 times since 2014), wines from fresh grapes (1.7 fold), wheat (3.7 fold), barley (1.7 fold) and fresh grapes (6.3 fold) and have all seen significant increases in exports. The zero-duty tariff rate quotas for plums and table grapes were surpassed. At the moment, tariff trade quotas apply to six products: grapes, fresh apples, tomatoes, plums, garlic and grape juice. Animal goods are only allowed to be exported to the EU in the form of honey and caviar (Cenusa et al., 2014).

Fears of a quick increase in EU imports were unfounded: the trade imbalance between Moldova and the EU decreased in 2018, compared to 2014, with the trade balance deficit falling by $25 \%$. As a result of the DCFTA's adoption, local products were more widely available on the EU market, helping to export growth and diversification. In reality, exports to the EU are more diverse than those to traditional export markets: shipments to Russia, for example, were dominated by wine and apples (Piras et al., 2021).

The rise in exports to the EU offset the losses incurred as a result of lower commerce with the Russian Federation as a result of the sanctions. Moldovan exports to Russia have dropped from $\$ 400$ million in 2014 to \$250 million in 2017. Meanwhile in 2018, the volume of agri-food exports to the EU grew by USD 515 million between 2015 and 2017, offsetting a USD 512 million drop in exports to Russia, Belarus, and Ukraine.

The DCFTA has favorable macroeconomic consequences as well: the net effect of exports to the EU is projected to be over EUR 367 million, results in the formation of over 15,000 employments, a 5\% rise in government income, and a EUR 320 million boost in private sector investment. However, there is still plenty of 
room for the DCFTA's promise to be fully realized. The majority of the preferred quotas free from customs taxes, such as those on apples, are still untapped (Certan and Certan, 2018).

Despite the fact that the tariff limitations on apples are established at 40000 tonnes, Moldova only exported 5000 to 6000 tonnes of apples in 2018. This is attributable to a shortage of infrastructure, as well as inadequate adherence to technical packaging standards, poor pre- and post-harvesting methods, and a lack of sufficient infrastructure. Another area where Moldovan agriculture lags is the export of animal-derived goods (dairy products, meat, and eggs) owing to a failure to meet EU requirements, which is frequently due to inadequate infrastructure (i.e., accredited animal-health laboratories) and a lack of investment in its repair. The AA/DCFTA legal equivalence is being worked on, however there will be significant delays in organic agriculture and animal health (Potopova et al., 2015).

Aside from the DCFTA, Moldova is a signatory to the Central European Free Trade Agreement (CEFTA), which took effect on May 1, 2007. Through trade liberalization, the pact encourages based on inter economic cooperation. It offers a predictable, consistent, and long-term legal framework that will help member nations promote bilateral and international trade. It advocates for the elimination of all customs tariffs on imports and exports, as well as quantitative limitations and other charges that have the same impact in the interchange of industrial and agro-industrial goods (Lerman and Cimpoies, 2006).

It has had a positive influence on commerce and investment in the area and with the EU since its creation. The CEFTA secretariat implemented a variety of programs to promote common standards of documents and processes in order to ease commerce among member nations. Another initiative is the Decision on Fruit and Vegetable Trade Facilitation, which not only streamlines the system of regulations for fruit and vegetable trade inside CEFTA, but also assures compliance with EU food safety requirements (Todorova and Sarbu, 2014).

\section{AGRI-FOOD TRADE FLOWS}

Agricultural and food items account for a significant portion of Moldova's export revenue. Its value has decreased significantly over the previous decade, but it still accounts for almost half of the country's exports. The entire value of exporting services and goods was 2779 million dollars, while imports totalled 5842 million dollars. Between 2001 and 2019, both imports and exports grew. In addition, both trade flows rose from 2015 to 2019 when compared to prior periods (2001-2014). Total exports grew by 66 percent in value, while imports increased by 45 percent (Stratan et al., 2015).

A similar pattern may be seen in the agri-food trade flows. Agricultural and food exports account for $43 \%$ of all traded commodities (2019). Agri-food items accounted for $45 \%$ of total exports on average between 2015 and 2019. Agrifood imports account for 14\% of all imported items. In 2015-2019, agri-food imports and exports both grew by 64 and 41 percent, respectively, as compared to the previous period. Agricultural products 
account for a larger part of overall agri-food trade flows in 2019, while food items account for around $30 \%$. Exports of agricultural goods rose modestly after 2008, but food imports have been on the rise since 2005 (Cimpoies, 2019).

Moldavian trade relations with European Union nations have changed dramatically in the previous two decades. After a first interdiction in 2005, the nation was forced to rethink its trading partners, which resulted in an increase in trade flows to the EU market. The entrance of Bulgaria and Romania to the European Union in 2007 contributed to a fresh surge in trade flows to and from E.U. nations. Moldova has also benefited from the General System of Preferences (GSP+) since 2006, as well as Autonomous Trade Preferences since 2008. This resulted in an increase in trade flows to EU nations as a result of free trade advantages for some items such as beverages, some agricultural products, sugar, and so on (Pila and Stanciu, 2019).

Moldova concluded a Deep and Comprehensive Free Trade Agreement with the European Union in 2014, enhancing the benefits of free trade even further. During the period 2015-2019, there were no major differences in the structure of most exported agri-food items. Six commodities, like previously, account for 85 percent of overall agrifood exports. Oleaginous fruits and Oil seeds, cereals, nuts and edible fruits, and drinks are currently in first place. At the same time, the structure of agricultural and food imports is becoming increasingly diversified. Thirteen commodities account for almost $70 \%$ of agri-food imports, including drinks, dairy products, oleaginous fruits, and oil seeds, among others. Agricultural goods account for $40 \%$ of them (Croucher, 2020).

Export heterogeneity characterizes Moldova's export competitiveness. As per the product mapping, there were few changes in the competitiveness of agrifood goods before and after the DCFTA was implemented. Few goods continue to retain Moldova's competitive advantage. The dominating positions had shifted. Cereals, seeds, oleaginous fruits, and oil as well as drinks, have previously retained their benefits (Potopova et al., 2015).

Nonetheless, with the introduction of the DCFTA, the structure of this category shifted in favor of nuts and edible fruits, vegetable, fruit and sugar, and nut preparations. This group's structure remained mostly same between before and after the DCFTA, with animal-derived goods, dairy products, edible vegetables, tobacco, live trees, and other items included. Moldova had a trade deficit, however with the DCFTA, it is a major exporter of three commodities: animal or vegetable fats or oils, vegetable planting materials, and drinks. Moldova has a negative effect and is a net importer of several specific aggregations, mostly imported "exotic" commodities such as seafood goods, coffee, cocoa and tea. This category has the smallest percentage of both agri-food exports and imports (Todorova and Sarbu, 2014).

\section{CONCLUSIONS}

Moldova should seek to implement the DCFTA since it is the most trustworthy economic and trade growth plan. Different investigations show that Moldova's best trade policy is to seek economic union and trade 
liberalization with the EU while also maintaining its discussion with Russia to expedite the removal of Russian trade restrictions against the country. The "simple" DCFTA scenario predicts a 7.6\% increase in Moldovan GDP at the conclusion of the transition period (2023) as contrasted to the baseline. Increased flow of foreign capital will considerably enhance this outcome if Moldova improves its local business climate. Moldova, on the other hand, must devote its energy and resources on removing backstage trade barriers in order to reap the maximum benefits from the DCFTA. Reduced transportation, logistics, and other commodity trading should be viewed as a top goal in this respect. Moldova needs to simplify its cargo clearance procedures for imports and exports, remove unnecessary trade documentation, and develop and implement standard operating procedures.

FUNDING: The authors did not receive any external funding.

CONFLICT OF INTEREST: The authors declare no conflicts of interest.

\section{REFERENCES}

1. Anderson, K., G. Rausser, \& J. Swinnen. 2014. “Agricultural Policy: A Global View”, In Encyclopedia of Agriculture and Food Systems, pp. 179-94.

2. https://doi.org/10.1016/b978-0-444-52512-3.00120-0

3. Awokuse, T. O. \& X. Ruizhi. (2014). Does Agriculture Really Matter for Economic Growth in Developing Countries?" Canadian Journal of Agricultural Economics/Revue Canadienne D'agroeconomie, Vol. 63, No. 1, pp. 77-99. https://doi.org/10.1111/cjag.12038

4. Caliendo, L., and E. Rossi. (2012).The impact of trade on organization and productivity. The quarterly journal of economics, 127(3), 1393-1467. https://doi.org/10.1093/qje/qjs016

5. Cantir, C., \& Kennedy, R. (2015). Balancing on the Shoulders of Giants: Moldova's Foreign Policy toward Russia and the European Union. Foreign Policy Analysis, 11(4), 397-416. https://doi.org/10.1111/fpa.12051

6. Cenusa, D., Emerson, M., Kovziridze, T., \& Movchan, V. (2014). Russia's Punitive Trade Policy Measures towards Ukraine, Moldova and Georgia. CEPS Working Documents, (400). Available at: https://www.files.ethz.ch/isn/184253/WD\%20300\%20Punitive\%20Trade\%20Measures\%20by\%20Russia.pdf

7. Certan, I., \& Certan, S. (2018). Aspects in the trade of the agricultural products in the republic of Moldova. Scientific Papers Series-Management, Economic Engineering in Agriculture and Rural Development, 18(2), 8592. Available at: http://managementjournal.usamv.ro/pdf/vol.18_2/Art11.pdf

8. Cimpoies, L. (2016). An Analysis of Moldova's Agri-food Products Competitiveness on the EU Market. Agriculture and Agricultural Science Procedia, 10, 532-538. https://doi.org/10.1016/j.aaspro.2016.09.030 
9. Cimpoieș, L. (2019). Agri-food trade and the EU market: opportunities and challenges for Moldova.

Ekonomichniy forum 3/2019. Available at:

http://dspace.uasm.md/bitstream/handle/123456789/6654/Cimpoies\%2c\%20L.\%204.pdf?sequence=1\&isAllowe $\mathrm{d}=\mathrm{y}$

10. Croucher, R. (2020). Trade union education and union strategy. Renewing agricultural unions in Moldova, the Ukraine and Russia. SEER-South-East Europe Review for Labour and Social Affairs, (01), 157-169. Available at: https://www.ceeol.com/search/article-detail?id=197469

11. EU Factsheet (2021). Agri-food trade statistical factsheet European Union - Moldova, European Commission, Directorate-General for Agriculture and Rural Development. Available at: https:/ec.europa.eu/info/sites/default/files/food-farming-fisheries/farming/documents/agrifood-moldova_en.pdf

12. Fathipour, G. \& A. Ghahremanlou. (2014). "Economical-Regional Integration - An Overview on Iran-India Trade Relation”, Procedia Social and Behavioral Sciences, Vol. 157, pp. 155-164. https://doi.org/10.1016/j.sbspro.2014.11.019

13. Garmann, S. (2014). Does Globalization Influence Protectionism? Empirical Evidence from Agricultural Support, Food Policy, Vol. 49, pp. 281-293. https://doi.org/10.1016/j.foodpol.2014.09.004

14. Gudim, A. (2014). Moldova within Wider Europe. Problems of Economic Transition, 48(3), 19-32. Available at: https://www.tandfonline.com/doi/abs/10.1080/10611991.2005.11049976?.journalCode=mpet20

15. Kemoklidze, N., \& Wolff, S. (2019). Trade as a confidence-building measure in protracted conflicts: the cases of Georgia and Moldova compared. Eurasian Geography and Economics, 61(3), 305-332. https://doi.org/10.1080/15387216.2019.1702567

16. Kumar, S. (2015). Regional Integration, Capital Mobility and Financial Intermediation Revisited: Application of General to Specific Method in Panel Data”, Journal of International Financial Markets, Institutions and Money, Vol. 36, pp. 1-17. https://doi.org/10.1016/j.intfin.2015.02.008

17. Lerman, Z., \& Cimpoies, D. (2006). Land consolidation as a factor for rural development in Moldova. EuropeAsia Studies, 58(3), 439-455. https://doi.org/10.1080/09668130600601933

18. Lileeva, A., and D. Trefler. (2010). Improved access to foreign markets raises plant-level productivity ... for some plants. The Quarterly journal of economics, 125(3), 1051-1099.

https://doi.org/10.1162/qjec.2010.125.3.1051

19. NBS (2021), National Bureau of Statistics of the Republic of Moldova. Available at: https://statistica.gov.md/index.php?1=en

20. Nilsson, M., \& Silander, D. (2016). Democracy and security in the EU's eastern neighborhood? Assessing the ENP in Georgia, Moldova, and Ukraine. Democracy and Security, 12(1), 44-61. https://doi.org/10.1080/17419166.2015.1135744

21. Ortikov, A., \& T. Vacek. (2018). Comparative advantage: products mapping of Uzbekistan's agricultural exports. In Agrarian Perspectives XXVII. Food Safety-Food Security, Proceedings of the 27th International Scientific Conference, 19-20 September 2018, Prague, Czech Republic pp. 203-209. Available at: https://www.cabdirect.org/cabdirect/abstract/20193108543 
22. Pila, M. M., \& Stanciu, S. (2019). Doing Business in Moldova. Case Study: Analysis of the Agri-food Sector. Risk in Contemporary Economy, 201-205. https://doi.org/10.35219/rce2067053222

23. Piras, S., Botnarenco, S., Masotti, M., \& Vittuari, M. (2021). Post-Soviet smallholders between entrepreneurial farming and diversification. Livelihood pathways in rural Moldova. Journal of Rural Studies, 82, 315-327. https://doi.org/10.1016/j.jrurstud.2021.01.006

24. Potopova, V., Boroneanţ, C., Boincean, B., \& Soukup, J. (2015). Impact of agricultural drought on main crop yields in the Republic of Moldova. International Journal of Climatology, 36(4), 2063-2082. https://doi.org/10.1002/joc.4481

25. Smith, A., Barbu, M., Campling, L., Harrison, J., \& Richardson, B. (2018). Labor regimes, global production networks, and European Union trade policy: Labor standards and export production in the Moldovan clothing industry. Economic geography, 94(5), 550-574. https://doi.org/10.1080/00130095.2018.1434410

26. Stratan, A., Fala, A., \& Clipa, V. (2015). Risks to the agri-food sector of Republic of Moldova associated with restrictions imposed by the Russian Federation on Moldovan imports. Procedia Economics and Finance, 32, 324-331. https://doi.org/10.1080/00130095.2018.1434410

27. Todorova, L., \& Sarbu, O. (2014). Innovation policy in agriculture and rural development of the European Union: Prospects for the Republic of Moldova. Available at: http://dspace.uasm.md:8080/xmlui/bitstream/handle/123456789/4387/art53\%20\%281\%29.pdf?sequence=1\&isA llowed $=\mathrm{y}$ 